\title{
Why not Activated? The Temporary Protection Directive and the Mystery of Temporary Protection in the European Union
}

\author{
Neden Yürürlüğe konmadı? Geçici Koruma Yönetmeliği ve Avrupa \\ Birliği'nde Geçici Koruma’nın Gizemi
}

\author{
H. Deniz GENÇ ${ }^{*}$ \\ N. Aslı ŞİRIN ÖNER ${ }^{* *}$
}

\begin{abstract}
Following the conflicts in former Yugoslavia, temporary protection was introduced as a crucial element of the European Union's (EU) response to refugee crises. The EU even adopted a directive, the Temporary Protection Directive, regarding its implementation. However, despite several refugee crises, it was not activated. Building on a comprehensive analysis of official documents of European institutions and the available secondary literature, this article investigates the main reasons behind its inactivation. It reveals that the real concerns of EU Member States lay in the measures promoting a balance of efforts to provide temporary protection. In other words, Member States' concerns over responsibility and burden sharing cast a shadow over temporary protection in the EU. The article concludes that the Directive's inactivation indicates a crisis of fundamental principles in European integration.
\end{abstract}

Keywords: asylum, European Union, refugee crisis, temporary protection, solidarity

Öz

Geçici koruma, Yugoslavyadaki çatışmaların ardından Avrupa Birliği’nin (AB) mülteci krizleri karşısında yürürlüğe koyacağı uygulamaların en önemli unsuru olarak ilan edildi. AB, uygulanmasına ilişkin bir 'Geçici Koruma Yönergesi' bile kabul etti. Ancak, bu zamana kadar yaşanan birkaç mülteci krizine rağmen, bu yönerge yürürlüğe konmadı. Avrupa kurumlarının resmi belgelerinin ve mevcut ikincil literatürün kapsamlı bir analizini temel alan bu makale, bu yönergenin yürürlüğe konmamasının ardındaki temel nedenleri araştırmaktadır. Makaleye göre, $\mathrm{AB}$ üye devletlerinin gerçek kaygıları, geçici koruma sağlama çabalarının dengesini destekleyen tedbirler konusunda yoğunlaşmaktadır. Başka bir deyişle, AB’de geçici koruma, üye devletlerin sorumluluk ve bütçe paylaşımı konusundaki endişelerinin gölgesi altında kalmaktadır. Makale, yönergenin yürürlüğe konmamasının Avrupa bütünleşmesinde bir temel ilkeler krizini gösterdiğini belirterek son bulmaktadır.

Anahtar Kelimeler: iltica, Avrupa Birliği, mülteci krizi, geçici koruma, dayanışma

* Asst. Prof., İstanbul Medipol University, Department of Political Science and International Relations, hdgenc@medipol.edu.tr, Orcid: 0000-0001-6319-8315

** Asst. Prof., Marmara University, Institute of European Studies, Department of European Politics and International Relations, asli.sirin@marmara.edu.tr, Orcid: 0000-0002-5392-0949 


\section{Introduction}

Temporary protection has been a constant theme of discussions regarding the international protection of refugees. In the 1970s, it was employed in providing international protection to Vietnamese refugees in Hong Kong and Thailand, Afghan refugees in Pakistan and Iran, Iranian refugees in Turkey and refugees in various Central American and African countries (Kjaerum, 1994; Fitzpatrick, 2000). Though employed since the early twentieth century, the conditions of temporary protection have needed clarification. In its 1979, 1980 and 1981 conclusions, the Executive Committee of UNHCR $(1979$, p. 3$)$ defined temporary protection by briefly noting that "in cases of large-scale influx, persons seeking asylum should always receive at least temporary refuge". The Executive Community referred to the 1951 Convention Relating to the Status of Refugees and its 1967 Protocol, which reaffirmed the principle of non-refoulement in providing temporary protection, underlined the responsibilities of the international community in assisting the first country of asylum, and noted that temporary protection should be used as a temporary, intermediate step on the way to a permanent solution (ibid: 1979; 1980; 1981). Following these basic delimitations, temporary protection has become the main form of international protection offered to persons arriving en masse since the 1990s. According to UNHCR (2005, p. 36), it is employed mainly by industrialized states as a short-term, emergency response while postponing determination of eligibility for refugee status. Refugee groups are received temporarily and offered protection according to minimum standards based on the principles of the 1951 Convention and its 1967 Protocol.

In line with this changing approach to the international protection of refugees, temporary protection was introduced as a crucial element of the European Union's (EU) response to refugee crises in the second half of the 1990s. In the following years, the EU mapped out the basics of temporary protection, adopting a directive on its implementation, the Temporary Protection Directive (Council Directive 2001/55/EC), in 2001. As explained below, its adoption was crucial because it introduced a Union-wide applicable legal mechanism to respond to mass arrivals of refugees. The Directive was the EU's concrete response to refugee crises. Interestingly, since its adoption, the EU has faced several humanitarian crises, namely Libya (2011), Tunisia (2011), Ukraine (2014) and Syria (2011 and ongoing). In each case, displaced persons arrived in EU Member States en masse. In particular, the mass movement of Syrian refugees has put huge pressures on EU institutions and front-line Member States. However, the TPD has not been activated in any of these crises.

Rather than activating the TPD and providing group-based temporary protection, EU institutions and Member States have focused on "the priority of keeping refugees out or at the periphery of the EU" and failed to meet expectations about their protection responsibilities (Parliamentary Assembly, Council of Europe, 29 September 2017, p. 2). This attitude not only contradicts Europe's international protection history but also leads many to question the founding common values of European integration: human dignity, freedom, equality, solidarity, principles of democracy and the rule of law (Charter of Fundamental Rights of the European Union, 2000). Thus, these refugee 
crises represent a crisis of Europe that forces us to consider Europe's failures in responding to them (Bauböck, 2018). In line with this thinking, this study examines the TPD. Building on document analysis and a comprehensive review of the available secondary literature, it presents a thorough discussion on the Directive and investigates the reasons for its non-implementation.

In discussing the reasons for this non-implementation, the study starts by outlining the genealogy of the EU's temporary regime and the evolution of the TPD. It proceeds by presenting the Union's international protection practices and discussions on TPD in the four refugee crises it has faced since adopting the Directive - Libya, Tunisia, Ukraine and Syria. The study then provides a thorough document analysis, drawing on primary sources from the Eur-Lex database, before concluding that the TPD has become obsolescent as a mechanism to respond to refugee crises in Europe.

\section{Methodology and limitations}

The study builds its discussion of the TPD by analysing official documents of various European institutions and the available secondary literature. The official documents were retrieved from the Eur-Lex database using the advanced search interface of the website. This search took place between September 4, 2017, and September 18, 2017. ${ }^{1}$ The database was first searched for the TPD's official number (2001/55/EC) and then together with the countries of origin in the four refugee crises that brought a mass influx of refugees since the TPD's adoption. The number of hits and their distribution by years for each search is presented in Table 1 below.

Table 1. Number of hits in Eur-Lex

\begin{tabular}{|l|l|l|l|l|l|}
\hline & & $2001 / 55 /$ EC & $2001 / 55 / E C$ & $2001 / 55 /$ EC & $2001 / 55 /$ EC \\
\cline { 2 - 6 } & & AND Tunisia & AND Libya & AND Ukraine & AND Syria \\
\hline TOTAL & 149 & 26 & 19 & 30 & 30 \\
\hline 2017 & 5 & 0 & 0 & 0 & 3 \\
\hline 2016 & 18 & 2 & 1 & 1 & 1 \\
\hline 2015 & 2 & 1 & 1 & 1 & 1 \\
\hline 2014 & 8 & 5 & 4 & 6 & 5 \\
\hline 2013 & 12 & 2 & 3 & 0 & 4 \\
\hline 2012 & 8 & 4 & 3 & 2 & 4 \\
\hline 2011 & 12 & 3 & 3 & 4 & 2 \\
\hline 2009 & 5 & 2 & 1 & 3 & 1 \\
\hline 2008 & 7 & 1 & 1 & 4 & 4 \\
\hline 2007 & 8 & 1 & 1 & 3 & 2 \\
\hline
\end{tabular}

1 After the paper was accepted for publication, the authors checked Eur-Lex database to check those documents published in 2018. This research (conducted on 8 February 2019) returned with 8 documents, which contained the official number of the Directive "2001/55/EC." These documents were not added to the analysis. 


\begin{tabular}{|l|l|l|l|l|l|}
\hline 2006 & 9 & 1 & 1 & 0 & 0 \\
\hline 2005 & 12 & 0 & 0 & 0 \\
\hline 2004 & 11 & 1 & 1 & 1 & 1 \\
\hline 2003 & 9 & 1 & 1 & 1 & \\
\hline 2002 & 5 & 1 & 1 & & \\
\hline 2001 & 9 & & & & \\
\hline 2000 & 2 & & & 1 & \\
\hline
\end{tabular}

Eur-Lex contained 149 documents including the TPD's official number. These public documents were prepared by various EU institutions: European Commission (55), European Parliament (46), Council of the European Union (25), Court of Justice (24), Economic and Social Committee (3), European Committee of the Regions (2) or others (9). ${ }^{2}$ In order to investigate the reasons behind the TPD's non-implementation, its official number was later searched together with the name of each country of origin for the four refugee crises. Although all documents including '2001/55/ EC' had already been identified, documents including both '2001/55/EC' and the name of each country of origin were re-examined. The authors perused these documents line by line and examined the paragraphs which note, refer or give information about the Directive, temporary protection and its application. They reviewed line, sentence and paragraph segments from the documents to code the data. The coding of the documents was based on three groups of search terms: (1) '2001/55/EC'; (2) temporary protection; (3) key words related to the Directive (influx, massive and displaced). The following discussion on TPD, its evolution, concerns about it and its non-implementation is organized around four main themes: TPD as the response; other asylum and migration mechanisms; failures to act; and solidarity.

\section{Temporary protection: the EU's instrument in refugee crises?}

Temporary protection in the EC/EU has its origins in the Yugoslav wars of dissolution. After war broke out in 1992, UNHCR introduced temporary protection as an element of its Comprehensive Response to the Humanitarian Crisis in Former Yugoslavia and urged states to introduce regimes to temporarily protect displaced Bosnians. Following this call, many EC states, like the Netherlands and Denmark, developed national schemes (van Selm-Thorburn, 1998). Several others, such as Spain, granted temporary protection based on specific laws while many others allowed people fleeing the war to stay on humanitarian grounds, including Greece, Portugal and Italy. In contrast, Ireland provided automatic temporary protection to all individuals admitted to Ireland whereas the UK granted Exceptional Leave to Remain (ELR) status. In short, European states introduced different schemes to admit displaced people temporarily during the conflict in former Yugoslavia. Similarly, there was no common approach concerning quotas for temporary protection, permitted length of stay, and the rights and entitlements to be provided to the Bosnians under temporary protection.

2 Sixteen of these documents were produced by the co-decision procedure, making the European Parliament and Council co-producers. 
While its Member States engaged in different practices of temporary protection, the EC showed its intention to collectively respond to the conflict. At the end of November 1992, the EC ministers responsible for immigration held a meeting in London where they adopted a Conclusion on People Displaced by the Conflict in Former Yugoslavia. Under this, EC Member States agreed to respect a number of guidelines including "readiness to offer protection on a temporary basis to those nationals of the former Yugoslavia" under certain conditions: the beneficiaries a) had to come "direct" from combat zones; b) had to be "within" an EU state's border; and c) could not return to their homes "as a direct result" of the "conflict" (Joly, 1996). The London meeting was followed by European Council meetings in Edinburgh (December 1992) and Copenhagen (June 1993). Though small steps were taken towards providing temporary accommodation and subsistence to displaced people, Member States were still unwilling to take any responsibility concerning burden-sharing. In order to highlight the need to address this reluctance, a Communication from the Commission on Immigration and Asylum Policies (February 1994) underlined the necessity for developing schemes for temporary protection and the need for solidarity to support frontline Member States (van-Selm Thorburn, 1998, p. 70). The communication also expressed concerns that the contents of the provisions for temporary protection varied between states and called for the harmonization of schemes to develop a uniform European scheme (European Commission, 1994, p. 93).

Though the issue of burden-sharing was one of the primary issues and a draft was prepared during the German EC Presidency in 1994, the efforts bore no fruit because of the opposition of those Member States that did not face an influx of asylum-seekers. However, only a year later, the Council adopted the Resolution on Burden-Sharing with Regard to the Admission and Residence of Displaced Persons on a Temporary Basis in 1995 (Official Journal, 1995, p. 10). This was followed by a Decision on an Alert and Emergency Procedure for Burden-Sharing with Regard to the Admission and Residence of Displaced Persons on a Temporary Basis in March 1996. These documents did not mention harmonization of Member States schemes. However, the introduction of the Treaty of Amsterdam, which communitarized various fields that were previously subject to intergovernmental co-operation under the Third Pillar (cooperation in Justice and Home Affairs, Article $\mathrm{K}$ of the TEU), opened the way for harmonization in immigration, asylum, visas and external borders. The treaty laid down precise actions, including temporary protection. According to Article 73k:

The Council, acting in accordance with the procedure referred to in Article 73o, shall, within a period of five years after the entry into force of the Treaty of Amsterdam, adopt:

$[\ldots]$

(2) measures on refugees and displaced persons within the following areas:

(a) minimum standards for giving temporary protection to displaced persons from third countries who cannot return to their country of origin and for persons who otherwise need international protection (European Communities, 1997, p. 27) 
However, before the Amsterdam Treaty entered into force, conflict broke out in Kosovo in 1998, displacing hundreds of civilians. ${ }^{3}$ As with the Bosnian case, there was no unified or collective approach to temporary protection so Kosovar evacuees were treated differently in each EU Member States. The crisis showed once again the need for harmonization of immigration and asylum measures. Following this crisis, and in line with the goals of the Amsterdam Treaty, the European Council in Tampere in 1999 called on the EU to develop common policies on asylum and immigration.

Following this meeting, several pieces of legislation related to asylum were formally adopted. The first was the TPD (2001/55/EC), comprising 9 chapters and 34 articles. Article 1 is about the TPD's main purpose, which is "to establish minimum standards for giving temporary protection in the event of a mass influx of displaced persons from third countries who are unable to return to their country of origin and to promote a balance of effort between Member States in receiving and bearing the consequences of receiving such persons". Article 2 presents agreed definitions of the concepts used in the Directive: 'temporary protection', 'Geneva Convention', 'displaced persons', 'mass influx', 'refugees', 'unaccompanied minors', 'residence permit' and 'sponsor.' 'Temporary protection', for instance, is defined as:

a procedure of exceptional character to provide, in the event of a mass influx or imminent mass influx of displaced persons from third countries who are unable to return to their country of origin, immediate and temporary protection to such persons, in particular if there is also a risk that the asylum system will be unable to process this influx without adverse effects for its efficient operation, in the interests of the persons concerned and other persons requesting protection;

As Arenas (2005, p. 438) notes, the key concept here is 'mass influx' because it marks the difference between the applicability of the regular asylum system and the applicability of the system of temporary protection under the TPD. Article 2 defines this key concept as follows:

the arrival in the Community of a large number of displaced persons, who come from a specific country or geographical area, whether their arrival in the Community was spontaneous or aided, for example through an evacuation programme.

The existence of a mass influx of displaced persons is determined by the Council and the decision is adopted by a qualified majority following a proposal from the Commission (Article 5). The duration of temporary protection is one year and might be extended automatically by six monthly periods for a maximum of one year (Article 4). It comes to an end (a) when the maximum duration has been reached; or (b) at any time, by Council Decision adopted by a qualified majority on a proposal from the Commission, which shall also examine any request by a Member State that it submits a proposal to the Council (Article 6) (Council Directive 2001/55/EC).

3 “600,000 Kosovar Albanians became refugees and 400,000 were internally displaced” (Barutciski and Suhrke 2001, p. 101). 
Articles 8-16 define the obligations of Member States towards persons benefitting from temporary protection. It is noteworthy that these articles speak of the "obligations" of Member States instead of the "rights of persons enjoying temporary protection" because this means that "the Member States are internationally obliged to grant temporarily protected persons a certain minimum treatment" (Kerber, 2002, p. 201). These obligations are concerned with residence permits and visas, information and readmission (Articles 8, paragraphs 1, 9 and 11); registration and data protection (Article 10); accommodation and housing (Article 13); social welfare and medical care (Article 13, paragraph 2); education (Articles 14 and 12, first sentence); and family reunification and unaccompanied minors (Articles 15 and 16).

According to the TPD, temporary protection status is an interim one between the persons applying for asylum and Convention refugees. Thus, persons under temporary protection have the right "to lodge an application for asylum at any time" (Article 17). Moreover, in the case of cessation of temporary protection, "the general laws on protection and on aliens in the Member States" (Article 20) applies, meaning that these beneficiaries continue to be protected. On the other hand, return is also emphasized, with Article 21 describing the obligation of Member States "to make possible the voluntary return of persons enjoying temporary protection or whose temporary protection has ended".

Solidarity is treated under Chapter IV in Articles 24-26. Article 24 refers to the European Refugee Fund while Article 25 notes that "The Member States shall receive persons who are eligible for temporary protection in a spirit of Community solidarity. They shall indicate [...] their capacity to receive such persons". Article 26, on the other hand, explains how transferal of residence of persons enjoying protection between Member States shall take place in a cooperative spirit (Council Directive 2001/55/EC). There is no reference to burden-sharing other than these articles.

The Treaty of Lisbon (2010) is also noteworthy in the context of the EU's asylum capabilities because it grants the EU new competences in the area of asylum (Article 78 of TFEU). Rather than establishing minimum standards, the EU is now able to adopt measures for the creation of a common system with uniform procedures. Among other features, this common system must include a uniform status of asylum and a common system of temporary protection valid throughout the EU (Kaunert and Leonard, 2012, p. 15).

Since the adoption of the TPD and the entry into force of the Treaty of Lisbon, the EU has faced several refugee crises. Following the uprisings in Tunisia in 2010 and Libya in 2011, Tunisians and Libyans arrived in large numbers by sea in two Mediterranean Member States - Italy and Malta. ${ }^{4}$ Italy, with the help of Malta, "officially formalized a request to start off the Temporary Protection system", but this request was rejected by the Justice Home Affairs Council and later by Commissioner Malmström (Notarbartolo di Sciara, 2016, p. 4). Although the solidarity principle

4 The number of Tunisians who fled was estimated to be 27,465 while the number of Libyans was around 12,100 (Nita, 2013, p. 1; IOM, 2011a). 
was reaffirmed, the request was turned down on the grounds that the inflows to Italy and Malta could not be regarded as a 'massive influx' because the numbers of asylum-seekers were not large enough to meet the TPD's criteria (Nita, 2013, p. 2).

The conflict in Ukraine, on the other hand, has displaced more than 2.8 million people internally and externally since April 2014, with Poland receiving the largest influx. UNHCR (2016) reports that as many as 119,000 Ukrainians applied for temporary residence between January 2014 and June 2016 while over a million entered the country with regular entry visas or via labour migration mechanisms. In its study on TPD, the European Commission (2016b) notes that Poland has not asked for the activation of EU temporary protection mechanisms.

Most recently, Syrian refugees have started crossing into Europe, in an influx in 2015. According to FRONTEX, more than 1.8 million migrants crossed via different routes (BBC News 4 March 2016). While European policymakers were well aware of this mass influx, it was academics, activists and social workers that called for the activation of the TPD in 2015 (Orchard and Miller, 2014; Yeo, 2015; Tsourdi and de Bruycker, 2015; İneli-Ciğer, 2016). Nevertheless, despite these calls, the EU has not even considered implementing the TPD regarding the Syrian refugee crisis. The following section considers the reasons behind its inactivation.

\section{Demystifying the mystery of the TPD}

Different studies, including the Commission's own study on the TPD discuss its evolution and lack of activation. According to Kerber (2002), EU Member States have disagreed about the instrument since the beginning, with problems concerning burden-sharing, the relationship between temporary protection and asylum procedures, and future long-term solutions. Other authors also suggest that the cumbersome and difficult activation procedure explains its nonimplementation. They note that activation requires complex legal evaluations and a long, strenuous political process to reach a compromise between Member States (Joannin, 2017, p. 4; Orchard and Miller, 2014; Notarbatola di Sciara, 2016; Gluns and Wessels, 2017). They explain that the decision to activate the TPD must be made by Qualified Majority Voting (QMV) with two thirds of the vote - a very high threshold for EU decision-making - especially when the crisis hits small Member States on the border (Akkaya, 2015; Notarbatola di Sciara, 2016). These authors also emphasize the ambiguous nature of the Directive's legal notions, notably 'mass influx', and argue that it is very difficult for Member States to reach a compromise in the absence of precise legal notions ( ibid). The fear of the 'pull-factor' - namely, the fear that activating the TPD might attract displaced people to Europe - is another suggested reason (Akkaya, 2015; Orchard and Miller, 2014). Finally, Akkaya (2015) underlines the requirement for burden-sharing in the event of the TPD's activation, which she claims is unpopular among small member states, particularly those with strained budgets.

The thorough analysis in the Commission's own study (European Commission, 2016b), on the other hand, notes that Member States' opinions about the instrument have diverged since 
the beginning and that the main issue is burden-sharing. Above all, both Member States and EU institutions, primarily the European Commission, face problems in clarifying 'temporary protection' and narrowing down the definition of 'mass influx', as well as the thorny political task of calling a flow as a mass influx. There are also questions about whether activating the TPD might undermine national sovereignty or act as a pull factor (ibid.). Our examination of documents in the Eur-Lex database indicates that the discussion on the TPD, its evolution, concerns about it and its non-implementation can be organized around four main themes: TPD as the response, other asylum and migration mechanisms, failures to act, and solidarity.

The earliest TDP-related documents in the Eur-Lex database are European Commission Proposals $(1997,2000)$ for temporary protection of displaced persons, Opinions of the Economic and Social Committee (2001) and the Committee of the Regions (2001) on the Commission Proposal, Amendment of the European Parliament (2001) and the TPD (2001/55/EC) itself. From these early documents, it can be understood that the attempts to establish a temporary protection regime with the TPD as its linchpin, were highly valued and welcomed by these institutions. They underlined the "pressing need for a special instrument to deal with mass influxes of displaced persons" (EcoSoc, 2001, p. 25) and noted that "no time must be lost in reaching agreement between the Member States with regard to giving temporary protection" (CoR, 2001, p. 7). Moreover, as seen from the replies given to an EP Member's question regarding Chechen refugees (Dupuis, 2001, p. 1) in the early 2000s, the mechanism was referred to as the response of the $\mathrm{EU}$ in the event of a mass influx:

In the case in point, an extraordinary operation to receive refugees has not been initiated as neither the Member States nor the Commission have considered it necessary. It should be noted that no international organisation has called for it. In this connection, it should be noted that on 20 July 2001 the Council adopted Directive 2001/55/EC on minimum standards for giving temporary protection in the event of a mass influx of displaced persons and on measures promoting a balance of efforts between Member States in receiving such persons and bearing the consequences thereof.

In response to another question from an EP member about what provisions the EU had prepared to tackle a mass influx of illegal immigrants or a huge wave of refugees into the territory of an EU Member States, the Council refers to the TPD once more as 'the response':

The Council would refer the Honourable Member to Council Directive 2001/55/EC [...] ('Directive on temporary protection') (Trakatellis, 2003a, p. 207).

As the response to a mass influx, several other documents such as Reports and Communications by the Commission and answers to questions from EP members, referred to the TPD as one of the EU's basic asylum mechanisms:

Following the entry into force of the Treaty of Lisbon, asylum policy is now regulated by Article 78 TFEU. The asylum acquis is essentially composed of four directives 
(Reception Conditions, Qualification, Asylum Procedures and Temporary Protection) and three regulations (Dublin, Eurodac and European Asylum Support Office) (European Commission, 2011b, p. 446).

It is also interesting to discover that the Council wanted to have an early warning for a possible mass displacement after the September 11 attacks. In this risk assessment, the Council asked the Commission to examine the possibility of temporary protection if people were displaced. This inquiry shows once more that the Directive was considered as the response to such a mass displacement. Additionally, it would not be wrong to say that the Council had a more responsible attitude about displacements in the 2000s:

At the extraordinary JHA Council of 20 September 2001, the Council agreed to examine urgently the situation in countries and regions where there was a risk of large-scale population movements as a result of heightened tensions following the attacks on the USA. Furthermore, it requested the Commission, in consultation with Member States, to examine the scope for provisional application of the Council Directive on temporary protection in case special protection arrangements would be required within the EU. This led to a specific monitoring in particular of the trends of asylum applications from Afghan nationals in EU Member States until spring 2002. On the basis of the analysis of the situation, a special arrangement was felt not necessary (European Commission, 2003, p. 20-21).

As our examination of the documents reveals, the response was enhanced by other migration and asylum measures in the following years since many of the documents referring to or mentioning the TPD were in fact about other EU migration and asylum measures. As one of the earliest EU asylum measures, the TPD was referred in preparatory acts (75) and later legislation (27) for other migration and asylum measures, introduced to establish the area of freedom, security and justice in the EU. During the 2000s, it was mentioned in documents about the European Refugee Fund, readmission rules among Member States, return policy for illegal residents, minimum standards for the reception of asylum seekers, family reunification and the Common European Asylum System. Since 2011, it has been referred to in preparatory acts and legislation on reception, qualification, the Asylum, Migration and Integration Fund, conditions of entry and residence of third country nationals for the purposes of research, studies, training, voluntary service, pupil exchange schemes or educational projects and au pairing, and on the conditions of entry and residence of third country nationals for the purposes of highly skilled employment. Many of these documents refer to the TPD to delimit the scope of the new legislation:

This Directive [Council Directive 2003/9/EC of 27 January 2003 laying down minimum standards for the reception of asylum seekers] shall not apply when the provisions of Council Directive 2001/55/EC of 20 July 2001 on minimum standards for giving temporary protection in the event of a mass influx of displaced persons and on measures promoting a balance of efforts between Member States in receiving such persons and bearing the consequences thereof are applied (Council of the European Union, 2003, p. 31). 
Another interesting point is the large number of Member States that failed to transpose the Directive. Although documents from the European Commission and Council noted the TPD as a basic asylum instrument, referring to it as "the response" of the union to a mass influx of refugees, the documents of European Court of Justice revealed that many Member States had failed to comply with the transposition deadline of 31 December, 2002. These were Belgium, Greece, Netherlands, Luxembourg, France, the United Kingdom and Ireland (European Court of Justice, 2004, 2005). In 2002, the union had 15 members although Denmark did not take part in the adoption of the TPD and was therefore not bound by it or subject to its application ${ }^{5}$, leaving 14 Member States to transpose the TPD. However, according to the documents, half can be considered as half-hearted about the Directive from the beginning as they delayed and failed to comply with the transposition deadline. According to a Commission Staff Document on Monitoring the Application of Community Law, national transpositions for the TPD should have been completed in 2007 (European Commission, 2008).

Interestingly, vagueness about the key concept of 'mass influx', which is, in the words of the European Commission (2013, p. 19), "the heart of the system", was mentioned in very few documents, and only after 2011. COR (2011, p. 2) called for a clear definition of "what constitutes a 'mass influx' of migrants", while EP (2012, p. 9) called on the Commission "to make it possible for [the TPD] to be activated even in cases where the relevant influx constituted a mass influx for at least one Member State and not only when it constituted such an influx for the EU as a whole." The European Commission (2013, p. 19), on the other hand, noted that the Directive "[left] wide room for manoeuvre, in the form of open definitions of key words, such as 'mass influx"'.

Other than these points about the approach to the TPD, delays in its transposition and relationship with other asylum and migration mechanisms, the emphasis on solidarity and responsibility sharing in its application were recurrent themes. With regard to responsibility sharing, it is worth noting that the temporary relocation scheme, which was kind of a response to the so-called "influx" taking place in 2015, could not be materialised because some of the member states such as Hungary resisted implementing the EU's quota system. ${ }^{6}$

5 The TPD's relationship with Denmark, UK and Ireland has proceeded differently as these states are outside the Schengen Zone and have opt-outs (derogations) regarding asylum and migration measures in the relevant treaties. Denmark did not take part in adopting the TPD so is not bound by it whereas the UK gave notice of its wish to adopt and apply it. Ireland, on the other hand, did not participate in the adoption but then requested to accept it in 2003 (Council of the European Union 2001).

6 A relocation scheme was introduced with the European Agenda on Migration, issued in the aftermath of a tragic incident taking place close to the Italian island of Lampedusa in which nearly 800 people drowned when an overcrowded boat capsized off the coast of Libya in April 2015. The aim of the scheme was to ease part of the burden from the EU's frontline states Greece and Italy (Sabic, 2017). persons in clear need of international protection would be distributed among the Member-states. "In July 2015, the Council agreed to relocate 40.000 refugees from Italy (24.000) and Greece (16.000). ... In September, the Council adopted a decision to relocate an additional 120.000 people from Italy and Greece" (Sabic, 2017: 5). Finland abstained while Hungary, Slovakia, the Czech Republic and Romania voted against the decision to relocate. In September 2016, the Hungarian Prime Minister Orban called for a referendum on the relocation scheme. According to the result of the referendum over $90 \%$ out of $43.7 \%$ of voters supported Orban's position, but the referendum was not valid according to the Hungarian law because turnout was well below 50\%. Yet, Orban did not accept the insufficient turnout as a defeat and celebrated victory (Sabic, 2017). 
As recurrent themes, the issues of solidarity and responsibility sharing were emphasized, questioned, explained and re-explained in many different documents from 2003 to 2016:

In the interests of solidarity, Article 24 of the Directive on temporary protection lays down that the measures provided for in the Directive shall benefit from the European Refugee Fund set up by Council Decision 2000/596/EC of 28 September 2000. Article 6 of that Decision provides for emergency funds, separate from the resources allocated to Member States each year by the Fund, to help one or more or all Member States in the event of a sudden mass influx of refugees or displaced persons, or if it is necessary to evacuate them from a third country, in particular in response to an appeal by international organisations (Answer by Council to a question from an EP Member, Trakatellis, 2003a, p. 207).

In an answer to a question by another EP member, the Commission explained:

The measures for implementing the Directive will be supported by the European Refugee Fund, in particular by releasing appropriations entered in the reserve. If that amount does not cover requirements in the event of a massive influx, extra funds may be granted with the agreement of the budgetary authority (Trakatellis, 2003b, p. 90).

In its Communication on Establishing a Framework Programme on Solidarity and the Management of Migration Flows for 2007-2013, the Commission (2005, p. 15) explained that the European Refugee Fund (ERF) was "the expression of solidarity" within the context of asylum, also noting its importance for the TPD:

The first expression of this solidarity was the creation of the ERF in 2000, on the basis of three years of preparatory actions. The Fund, which was backed by the European Parliament and based on a proposal by the Commission, has been instrumental in laying the foundations of collective action by the Community for the reception of asylum-seekers and people requiring international protection as part of a comprehensive approach. It has also helped to secure agreement on the Directive on temporary protection in the event of a mass influx of displaced persons.

In another Communication in 2006, the Commission (2006, p. 6) referred to a few Member States' concerns about the burdens and means to provide solidarity within the framework of the TPD. It is noted that its instruments were not sufficient to cope with pressures on asylum services and reception capacities, and that ensuring effective burden-sharing was "both politically sensitive and technically difficult". It continued:

While the Temporary Protection Directive provides for solidarity between Member States in the event of a mass influx of displaced persons, its specific requirements do 
not provide an adequate response to the kind of particular pressure on asylum services and reception capacities more frequently experienced by Member States. These pressures have been characterised by the arrival of several hundred persons of different nationalities at particular points on the external border, seeking entry to the EU for one reason or another, some for protection.

Many subsequent documents revealed these concerns about burden sharing. They emphasized the need for fair burden sharing, mentioned the ERF, called for enhanced solidarity and, though they accepted the fragility of the efficacy of the mechanisms adopted to this end, they tried to build confidence among Members:

A reserve has recently been established for emergency measures (10 million each year). This reserve can, from 2008, be used to address 'particular pressures situations resulting from sudden arrivals of large numbers [...] which place significant and urgent demands on Member States' reception facilities or asylum systems. It is however too early to assess the efficacy of this mechanism (European Commission 2009, p. 12).

The European Commission (2011a, p. 16) referred to the same issues in its proposal for the Asylum and Migration Fund:

It is important for enhanced solidarity that the Fund provides additional support to address emergency situations of heavy migratory pressure in Member States or third countries or in the event of mass influx of displaced persons, pursuant to Council Directive 2001/55/EC [...] through emergency assistance.

Additionally, calls for activation were made in various COR and EP documents. COR (2011, 2012 , p. 6) suggested that the TPD "should be reviewed and revised to define more clearly what constitutes a 'mass influx' of migrants" while the EP (2012, p. 24) called "on the Commission to make it possible for this Directive to be activated even in cases where the relevant influx constitutes a mass influx for at least one Member State". However, they did not respond. Rather than making its activation possible, the Commission (2016b) prepared a thorough study on the TPD. Interestingly, however, even before this study was released, the Commission (2016a, p. 7) proposed to reform the Dublin system and called on Member States to consider repealing the Directive:

The Commission intends to put forward, as a matter of priority, a proposal to reform the Dublin system. Two main options for reforming the determination of responsibility under the Dublin system should be considered at this stage. Under both options, Member States of first point of entry should identify, register, and fingerprint all migrants, and return those not in need of protection. Moreover, as a further expression of solidarity, EU funding in relation to both options may need to be considered. As both options would be designed to address situations of mass influx, consideration could also be given to repealing the Temporary Protection Directive. 
In footnote 16, the Commission (2016a, p. 7) explained the inactivation of the Directive as follows:

This EU asylum instrument, intended to be activated in response to the mass influx of persons in need of international protection, has never been triggered, due primarily to its lack of an in-built compulsory solidarity mechanism to ensure a fair sharing of responsibility across Member States.

Following these lines, we can emphasize that, as already indicated by its name, the Directive has had two main aims: to codify the minimum standards for giving temporary protection in the event of a mass influx of displaced persons; and [the compromise] on measures promoting a balance of efforts between Member States in receiving such persons and bearing the consequences thereof. As can be understood from the documents, there have been hardly any problems, questions or discussion about the first aim as we found no document concerned with the minimum standards of temporary protection. Instead, concerns were focused on the second aim of the TPD: measures promoting a balance of efforts between Member States in receiving a mass influx. As the Commission (ibid.) explained, the Directive lacked an in-built compulsory solidarity mechanism that would convince Member States to give their consent for a political agreement on activating the TPD. However, we suggest that the overemphasis of these concerns, repetitive explanations, reassurances and reassurance about fair burden-sharing indicate a much deeper problem of confidence and solidarity among Member States.

\section{Conclusion}

Following the conflicts in the former Yugoslavia and Kosovo, temporary protection was introduced as a crucial element of the EU's response to refugee crises. Yet, despite several crises and influxes of displaced people into Europe, the TPD, which codified temporary protection to deal with this issue, has never been activated. In particular, during recent refugee crises involving Tunisia, Libya, Ukraine and Syria, both the EU and its Member States have failed to meet expectations about their protection responsibilities - contrary to Europe's international protection history. In the absence of group-based temporary protection, asylum-seekers escaping from similar conditions were treated differently in each Member State. Some continued to move around within the EU while many remained stuck outside the EU's borders, with front-line Member States placed under heavy pressure and burden.

The collective inability to respond to these refugee crises indicate a crisis in European integration, leaving many with questions about the founding common values of EU integration. To contribute to this discussion, this study has offered a thorough discussion on the TPD and explain why it was not activated in recent refugee crises. As presented above, analysis of primary documents from the Eur-Lex database created a discussion around four main themes: the TPD as the response, other asylum and migration mechanisms, failures to act and solidarity. Considering these documents 
together with the secondary sources, the study indicates that the TPD has become obsolete for legal and political reasons.

The most notable legal factors preventing the activation of the TDP are the complicated legal assessment and the lengthy, strenuous political process needed to reach agreement between Member States on the decision to activate the TPD. Reaching the necessary political agreement between Council members has been particularly difficult, exacerbated by QMV with the very high threshold of a two-thirds majority to trigger activation. In addition, the activation process itself is unacceptably time-consuming for refugee crises. Finally, ambiguity over the key concept in the TPD - 'mass influx' - has led Member States to adopt different, particularly narrow interpretations and a wide appreciation margin for the EU Council.

Among the political reasons, the fear of TPD attracting more refugees to Europe and concerns about burden-sharing related to this fear are prominent. Member States have had deep concerns especially about burden-sharing, as frequently expressed in the documents, with repetitive explanations by the EU institutions and reassurances about fair burden-sharing. New MemberStates, especially Hungary, have cast a shadow on burden-sharing by opposing the refugee relocation scheme and not implementing the temporary protection system. Perhaps they have been more negative than any of the core states of the Union. Opposing burden-sharing is an indicator of the lack of solidarity among the Member-States. Furthermore, our findings indicate a much deeper problem of confidence and solidarity among Member States. Steinvorth (2017, p. 9-11) describes solidarity as "a bond that makes up a 'we", which involves "the virtue of equals who help one another in misfortunes they are not responsible for". Solidarity has been a fundamental principle of European integration so expressed concerns about burden-sharing and guaranteeing balanced efforts (minimal in many cases) among Member States in providing temporary protection shows that they have deeper problems of confidence and trust each other and in the mechanisms of European integration. Thus, it would not be wrong to conclude that inactivation of the TPD indicates a crisis of the fundamental principles of European integration. As a last word, with this diagnosis of fundamental principles' crisis of European integration in our hands, we note that this thorough discussion on TPD bring us many different questions for future research on the future nature of the EU policy-making in the field of migration and refugee protection in Europe. Since the lack of political will again be on the stage, how to eliminate this lack will be one of the most complicated questions.

\section{References}

Akkaya, K. (2015) "Why is the Temporary Protection Directive Missing from the European Refugee Crisis Debate?” http://atha.se/blog/why-temporary-protection-directive-missing-european-refugeecrisis-debate (accessed 21 December 2017).

Barutciski, M., and A. Suhrke (2001) "Lessons from the Kosovo Refugee Crisis: Innovations in Protection and Burden-Sharing." Journal of Refugee Studies, 14 (2): 95-134. doi: 10.1093/jrs/14.2.95. 
Bauböck, R. (2018) "Refugee Protection and Burden Sharing in the European Union." Journal of Common Market Studies, 56 (1): 141-156. doi: 10.1111/jcms.12638.

Charter of Fundamental Rights of the European Union (2000) http://www.europarl.europa.eu/charter/pdf/ text_en.pdf (accessed 09 November 2017).

Council of the European Union (2001) "Council Directive 2001/55/EC of 20 July 2001 on minimum standards for giving temporary protection in the event of a mass influx of displaced persons and on measures promoting a balance of efforts between Member States in receiving such persons and bearing the consequences thereof." Journal of the European Communities (6.2.2003), L 212/12-21223.

Council of the European Union (2003) "Council Directive 2003/9/EC of 27 January 2003 laying down minimum standards for the reception of asylum seekers." Journal of the European Communities, (6.2.2003), L 31/18-L 31-25.

Dupuis, O. (2001) “Written Question E-2372/01 to the Council.” Official Journal of the European Communities $\mathrm{C} 81 / \mathrm{E} / 164$.

European Commission (1997) "Proposal to the Council for a Joint Action based on Article K. 3(2) (b) of the Treaty on European Union concerning temporary protection of displaced persons." COM (97) 93 Final.

European Commission (2000) "Proposal for a Council Directive on minimum standards for giving temporary protection in the event of a mass influx of displaced persons and on measures promoting a balance of efforts between Member States in receiving such persons and bearing the consequences thereof." Journal of the European Communities, (31.10.2000), C 311 E/251-257.

European Commission (2003) Communication from the Commission to the Council and the European Parliament on the common asylum policy and the Agenda for protection, COM (2003) 152 final.

European Commission (2005) Communication from the Commission to the Council and the European Parliament: Establishing a framework on Solidarity and the Management of Migration Flows for the period 2007-2013, COM (2005) 123 final.

European Commission (2006) Communication from the Commission on Strengthened Practical Cooperation, New Structures, New Approaches: Improving the Quality of Decision Making in the Common European Asylum System, COM (2006) 67 final.

European Commission (2008) Commission Staff Working Document accompanying the $25^{\text {th }}$ Annual Report on Monitoring the Application of Community Law, SEC (2008) 2854, Brussels.

European Commission (2009) Commission Staff Working Document: Accompanying Document to the Proposal for a Regulation of the European Parliament and of the Council Establishing an European Asylum Support Office, COM (2009) 66 final.

European Commission (2011a) Proposal for a Regulation of the European Parliament and of the Council establishing the Asylum and Migration Fund, COM (2011) 751 final.

European Commission (2011b) Commission Staff Working Document: $28^{\text {th }}$ Annual Report on Monitoring the Application of EU Law (2010), COM (2011) 193 final.

European Commission (2013) Commission Staff Working Document: Climate Change, Environmental Degradation, and Migration, SWD (2013) 138 final.

European Commission (2016a) Communication from the Commission to the European Parliament and the Council Towards a Reform of the Common European Asylum System and Enhancing Legal Venues to Europe. COM (2016) 197. 
European Commission (2016b) Study on the Temporary Protection Directive: Final Report. Brussels: European Commission.

European Court of Justice (2004) "Actions brought against Luxembourg Netherlands, French Republic." Official Journal of the European Union, C 314/7-8.

European Court of Justice (2005) “Actions brought against Greece, Belgium, United Kingdom and Ireland." Official Journal of the European Union, C 6/32 - 36.

European Parliament (2001) "Amendment to the Proposal for a Council directive on minimum standards for giving temporary protection in the event of a mass influx of displaced persons and on measures promoting a balance of efforts between Member States in receiving such persons and bearing the consequences thereof." (COM (2000) 303 C5-0387/2000 2000/0127(CNS)), Journal of the European Communities, (5.12.2001), C 343/82-89.

European Parliament (2012) "European Parliament Resolution of 11 September 2012 on Enhanced intra-EU solidarity in the field of asylum." Official Journal of the European Union, C 353/16-26.

Executive Committee of UNHCR (1979) No. 15 Refugees Without an Asylum Country. Conclusions on the International Protection of Refugees, Session XXX.

Executive Committee of UNHCR (1980) No. 19 Temporary Refuge. Conclusions on the International Protection of Refugees, Session XXXI.

Executive Committee of UNHCR (1981) No. 22 Protection of Asylum-Seekers in Situations of Large-Scale Influx. Conclusions on the International Protection of Refugees, Session XXXII.

Fitzpatrick, J. (2000) “Temporary protection of refugees: elements of a formalized regime.” American Journal of International Law 94(2): 279-306. doi: 10.2307/2555293.

Gluns, D., and J. Wessels (2017) "Waste of Paper or Useful Tool?: The Potential of the Temporary Protection Directive in the Current Refugee Crisis." Refugee Survey Quarterly 36 (2): 57-83. doi: 10.1093/rsq/ hdx001.

İneli-Ciğer, M. (2016) "Developing Better Responses to the Asylum Crisis in Europe and Syria Refugee Crisis: What Should be the Role of Temporary Protection?" https://blogs.uta.fi/eura-net/2016/06/03/ developing-better-responses-to-the-asylum-crisis-in-europe-and-syria-refugee-crisis-whatshould-be-the-role-of-temporary-protection/ (accessed 19 August 2017).

Joannin, P. (2017) "Dublin and Schengen - Restoring confidence and strengthening solidarity between Member States of the European Union." Robert Schumann Foundation, European Issue no 434.

Joly, D. (1996) Haven or Hell? Asylum Policies and Refugees in Europe. Great Britain: Macmillan Press.

Kerber, K. (2002) “The Temporary Protection Directive." European Journal of Migration and Law (4): 193214. doi: $10.1163 / 157.181 .602400287350$.

Kjaerum, M. (1994) “Temporary Protection in Europe in the 1990s.” International Journal of Refugee Law 6 (3): 444-456. Doi: 10.1093/ijrl/6.3.444.

Notarbartolo di Sciara, M. (2016) “Temporary Protection Directive, Dead Letter or Still Option for the Future? An Overview on the Reasons Behind its Lack of Implementation." Eurojus.it, http://rivista. eurojus.it/temporary-protection-directive-dead-letter-or-still-option-for-the-future-an-overviewon-the-reasons-behind-its-lack-of-implementation/?print=pdf

Orchard, C., and A. Miller (2014) Protection in Europe for Refugees from Syria. Oxford: Refugee Studies Center.

Parliamentary Assembly, Council of Europe (29 September 2015) Resolution 2073 (2015) Countries of Transit: Meeting New Migration and Asylum Challenges, http://assembly.coe.int/nw/xml/XRef/ Xref-XML2HTML-en.asp?fileid=22175\&lang=en (accessed 3 November 2017). 
Selo Sabic, S. (2017), “The Relocation of Refugees in the European Union: Implementation of Solidarity and Fear", Friedrich Ebert Stiftung Zagreb, Analysis

Steinvorth, U. (2017) 'Applying the Idea of Solidarity to Europe', in A. Grimmel and S. Giang (eds.), Solidarity in the European Union: A Fundamental Value Crisis, Hamburg: Springer, 9-19.

Tsourdi, E. L., and P. de Bruycker (2015) EU asylum policy: In search of solidarity and access to protection, European University Institute, Migration Policy Center. http://cadmus.eui.eu/bitstream/ handle/1814/35742/MPC_PB_2015_06.pdf?sequence=1\&isAllowed=y (accessed 18 August 2017).

The Committee of the Regions (2001) 'Opinion of the Committee of the Regions on the 'Proposal for a Council Directive on minimum standards for giving temporary protection in the event of mass influx of displaced persons and on measures promoting a balance of efforts between Member States in receiving such persons and bearing the consequences thereof", Official Journal of the European Communities, (14.12.2001), C 357/6-10.

The Committee of the Regions (2011) "Resolution of the Committee of the Regions on 'Dealing with the impact and consequences of revolutions in the Mediterranean." Official Journal of the European Union, C 192/01-03.

The Committee of the Regions (2012) "Opinion of the Committee of the Regions on 'Enhanced intra-EU solidarity in the field of asylum." Official Journal of the European Union, C 277/12-18.

The Economic and Social Committee (2001) "Opinion of the Economic and Social Committee on the 'Proposal for a Council Directive on minimum standards for giving temporary protection in the event of a mass influx of displaced persons and on measures promoting a balance of efforts between Member States in receiving such persons and bearing the consequences thereof.' Official Journal of the European Communities, (29. 05.2001), C 155/22 - 28.

Trakatellis, A. (2003a) “Written Question P-0479/03 to the Council." Official Journal of the European Communities C222 E/207-208.

Trakatellis, A. (2003b) "Written Question E-0481/03 to the Commission." Official Journal of the European Communities. C11 E/89-C11 E/91.

UNHCR (2005) An Introduction to International Protection: Protecting persons of concern to UNHCR, Geneva: Office of the UNHCR.

UNHCR (2016) The Situation of Ukrainian Refugees in Poland, https://www.ecoi.net/file_ upload/1930_147.565.7937_57f3cfff4.pdf (accessed 18 August 2017).

van Selm-Thorburn, J. (1998) Refugee Protection in Europe: Lessons of the Yugoslav Crisis. The Hague/ Boston/London: Martinus Nijhoff Publishers.

van Selm, J. (2015) 'Temporary Protection: EU had a plan for migrant influx', EU Observer, https:// euobserver.com/opinion/130678 (accessed 18 August 2017).

Yeo, C. (2015) “Is it time to invoke the EU’s Temporary Protection Directive for Syrian refugees?” https:// www.freemovement.org.uk/is-it-time-to-invoke-the-eus-temporary-protection-directive-forsyrian-refugees/ (accessed 18 August 2017) 